\title{
Diachronic variation and the lexical field. Theoretical and practical implications
}

\author{
Dinu Moscal* \\ “A. Philippide” Institute of Romanian Philology, Str. T. Codrescu 2, 700481 Iași, Romania
}

\begin{abstract}
Article info
History:

Received May 3, 2015

Accepted June 14, 2015

Published July 17, 2015

Key words:

diachrony

language evolution

dialectal differentiation

history of language

historical semantics
\end{abstract}

\begin{abstract}
This paper tackles the importance of diachronic variation within the framework of the research dedicated to the lexical field, as well as the implications at the level of practical applications. Two major research perspectives can be distinguished in the field, the traditional one, lacking the adequate technicalities for semantic research, and the modern one, benefiting from the contributions brought about by structural linguistics. The importance of diachronic variation is highlighted for each perspective, next to its impact at the practical level. If in the case of the former perspective the diachronic variation of an onomasiological field is a defining trait, the theoretical framework of the modern perspective excludes the inquiry into a variation of a field, diachronically as much as synchronically. In the final part of the article we focus on the importance of describing, from a modern perspective, a lexical field, at every level of its variation, be it synchronic or diachronic. This leads to a more exact identification of the significance of words belonging to a certain field, within the framework of each version of a historical language. The utility of these results is also exemplified against the background of lexicography.
\end{abstract}

\section{General framework}

The phrase "lexical field" is immediately associated with the idea of researching a certain group of words, which is essentially true, but this truth must not be mistaken for the purpose of lexical field analysis, which does not imply analysing the lexical field itself, but distinguishing an identity-as clear as possibleof the significant elements of language, the lexemes (or, using a wider definition, words), based on the relationships developed between them within certain paradigms, at a semantic level. In reality, the analysis of lexical fields (also called semantic fields) is nothing more than the continuation of Saussure's endeavour of providing consistency to the concept of "linguistic value", in view of the associative relationships based on the analogy of the signified (Saussure, 1922, p. 171).

Identifying through difference is in fact a primary act of perception in humans, correlated with the proximate genus, but not with the variables in constructing it. The first confrontation with variability in defining through proximate genus and specific difference is probably to be found in Diogenes Laertios's story with Plato being forced to reconsider the definition of "man" as a result of the artificial modification of a rooster by Diogenes the Cynical. Thus, the definition of man as being "two-legged and featherless", allegedly completed with "having broad nails" (Diogenes, 2001, p. 203). Diogenes' challenge, who brought a plucked rooster in front of Plato, is of course anecdotal, but Plato's reply is a simple an illustration as possible for the way in which one variable can influence the process of defining through proximate genus and specific difference.

The same process is pointed out by Saussure in the case of distinguishing linguistic units, focusing on the importance of the concept of "linguistic value": "En outre l'idée de valeur, ainsi déterminée, nous montre que c'est une grande illusion de considérer un terme simplement comme l'union d'un certain son

*Email address: dinumoscal@yahoo.com. 
Dinu Moscal

avec un certain concept. Le définir ainsi, ce serait l'isoler du système dont il fait partie; ce serait croire qu'on peut commencer par les termes et construire le système en en faisant la somme, alors qu'au contraire c'est du tout solidaire qu'il faut partir pour obtenir par analyse les éléments qu' il renferme" (Saussure, 1922, p. 157).

Identifying linguistic units through difference-or, using a term more widely used in linguistics, through opposition-implies another primary aspect, namely the fact that language is not a nomenclature. Saussure's statement involves the designative level, and cannot be negated, even if in some cases reference can be made to a nomenclature as well. But this aspect must be highlighted at the level of language significance, too. Similar to the absence of a biunique correspondence between the elements of a series of names and the elements of a series of things, there is no biunique correspondence between the elements of the series of the signifying and that of the signified. In other words, language possesses no trait typical to a nomenclature - neither at the level of representation, nor at the level of signification. Of course, no claim has been made about language not being a nomenclature at the level of signification, but this perspective on things is necessary in order to prove the "why" and "how" of it not being a nomenclature in our contextualization. The theoretical response is the one provided by Saussure in the quotation mentioned above, continued through the discussion about the associative relationships based on the analogy of the signified. This research direction, fundamental through its subject, was continued through the objective of discovering this relationships at the paradigmatic level of language, disclosing the existence of certain groups, called lexical fields or semantic fields, an objective particularly visible since the 1930's.

\section{Research objective}

The concept of "lexical field" is almost a century old, and the various theoretical approaches have focused on the linguistic distinctions of primary importance at the general level of language studies during this

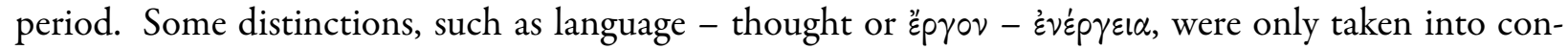
sideration at the beginning of the studies in the field (Trier, 1973a, p. 1-8), while in other cases the distinctions were approached differently, which led to various representations of the lexical field (Jolles, 1973; Porzig, 1973). The distinction synchrony - diachrony is essential throughout the entire array of research, methodologically as well as objectively, in other words, in delineating theoretically the subject of the study - the lexical field - as well as actually analysing it. The objective of the present paper is to assess the impact of the diachronic perspective across these two approaches and emphasizing the utility of such an analysis, particularly in using the data gathered in lexicographical papers.

\section{The traditional perspective and the modern perspective}

The history of research in this field indicates the existence of two major, distinctive stages, proven by their respective main objectives: a stage in which one brings forth arguments in favour of the existence of lexical fields, naturally implying efforts to delineate this research subject, and a second stage, based on describing the relationships between the elements forming a lexical field and distinguishing them from other types of relationships, corresponding to other categories of lexical paradigms. The first stage is represented by German lexicology between the 1930's and 1960's, first and foremost through the two great German lexicologists, Jost Trier and Leo Weisgerber. The second stage is represented by Eugenio Coseriu's studies, which re-analyse the entire problematics resorting to the tools of structural linguistics. Two approaches correspond to these two stages, approaches that are scientifically different and mostly determined by their main objective, as well as the stage of linguistics at that particular time. Thus, two different perspectives are to be acknowledged, names, as follows, "the traditional perspective" and "the modern perspective", respectively. 


\section{The traditional perspective and the diachronic variation}

The studies from the first stage do not reveal a unitary vision on the concept of "lexical field", but the most coherent theory, and also the one that eventually achieved mainstream status, was Trier's, supported and continued by Weisberger, providing the first typology of lexical fields as well (Weisgerber, 1973).

In his endeavour to study German vocabulary up to the $13^{\text {th }}$ century, in a search for a better grasp of the concept of "knowledge" ("Verstand" in Old German), Trier (1973a) tries to find a manner of presentation which would surpass the rather intuitive modality of simply stating the semantic content of words. In order to do this, Trier focuses on establishing a unified perspective and research method, allowing him to demonstrate the interdependence and the transfer of semantic content between the words forming a semantic paradigm based on relationships at the lexical level. Unlike the previous attempts in the field, Trier seeks to specify the level of the language at which a lexical field is created and the nature of the relationships forming between the words constructing it. The modality acknowledged as the most adequate for understanding language at the lexical level is to perceive it as a whole, within which conceptual units can occur, defined through their relationships to the lexical units that are the closest as regards their semantic content: "Sprachinhaltsforschung ist Gliederungsforschung [...]. Denn man kann wohl von einer Ganzheit und ihrer Gliederung zum einzelnen Element, dem Wort gelangen, aber es ist hoffnungslos, durch Reichung von Wortbedeutungen zum Ganzen des Wortschatzinhaltes vordringen zu wollen. Man gelangt durch Reihung und Zusammenzählung nie zum Ganzen" ["To study the content of language is to study its structure [...]. Because one can undoubtedly reach the part-in this case, the word-starting from the whole and its structure, but the intention of reaching the linguistic content of vocabulary as a whole through citing the significations of words is hopeless. Through citing and adding one can never grasp the whole"] (Trier, 1973b, p. 117). This perspective takes after Saussure's, who also analyses the concept of "value": "En outre l'idée de valeur, ainsi déterminée, nous montre que c'est une grande illusion de considérer un terme simplement comme l'union d'un certain son avec un certain concept. Le définir ainsi, ce serait l'isoler du système dont il fait partie; ce serait croire qu'on peut commencer par les termes et construire le système en en faisant la somme, alors qu'au contraire c'est du tout solidaire qu'il faut partir pour obtenir par analyse les éléments qu'il renferme" (Saussure, 1922, p. 157). To demonstrate the existence of lexical fields, but particularly for offering them an identity, Trier resorted to certain general linguistic distinctions, which we would later find in Coseriu (2001b) under the name "primary distinctions" ("distinctions préalables"). The distinctions considered by Trier are the following: language

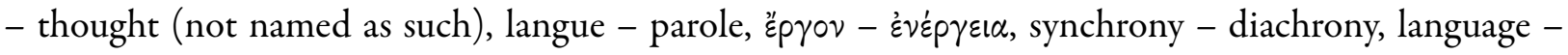
reality (Trier, 1973a, p. 1-26; cf. Moscal, 2013, p. 40-63).

The distinctions are being discussed with reference to language in general, but also with reference to the lexical level of language, where lexical fields should become noticeable, representing the linguistic structuring of the corresponding (albeit not ordered) conceptual complex (Trier, 1973a, p. 1). Except for the last dichotomy, language - reality, which is essentially a distinction between the linguistic and the extra-linguistic, in the case of the other dichotomies the lexical field is never clearly situated on one side or the other.

As regards synchrony and diachrony, clearly the relationships between the elements of a lexical field can only be properly identified within the realm of synchrony. The association with the static, and, respectively, the dynamic in language has been and still is a fact generally accepted in linguistic studies. The synchronic perspective is associated with the study of a certain "status" of language, while the diachronic one focuses on studying the evolution of a language unit. Taking into account the relatively modest dimensions of a lexical field, Trier considers that both perspectives can find a place in his research, in the sense that a diachronic analysis can be added to delineating the lexical field synchronically. Thus, if we resort to Saussure's terminology, the lexical field is simultaneously a synchronic and a diachronic reality. Otherwise, Trier refers to this separation between synchronic and diachronic realities (and identities), stating that the diachrony of a field represents a step forward from the direction established by Saussure in 
this field: "Saussure hat den Schritt nicht getan, der hier versucht wird: von Querschnitt zu Querschnitt springend die Strukturgeschichte eines Feldes zu geben" "Saussure did not take the step which we attempt to make here: highlighting the history of the field structure moving from section to section"] (Trier, 1973a, p. 13). Trier thinks that the relationships between the elements of language and its whole do not solely belong to synchronic linguistics, and that diachronic linguistics should not limit itself to analysing isolated lines, as in the history of a certain linguistic fact in various synchronic stages, following Saussure's view. Moreover, he believes that separating synchronic linguistics from diachronic linguistics is a scientific monstrosity (Trier, 1973b, p. 118-119). Trier does not accept the association between synchronic and static, due to the historicity of language: "Es ist kein Einwand gegen Saussure, wenn man behauptet, die Sprache als ein historisch Gewordenes unewig sich Wandelndes spotte der Einordnung in die Fächer und Schublade nirgend welcher statischer Ordnungen" ["It is not criticism pointed to Saussure to claim that language, marked by history and permanent transformation mocks the over-orderly distribution in shelves and drawers of a static disposition"] (Trier, 1973a, p. 11-12).

Trier analyses the lexical field of the German "Verstand" (knowledge), highlighting the evolution of its transformation from the initial state, represented through three terms: wisheit, kunst, and list. Initially, wish heit (wisdom, with the meaning of "spiritual knowledge/ cognition, linked to divinity and morality"), had a scientific character superordinate to the ones represented by kunst (art, with the meaning of "theoretic knowledge, reserved to the Court", which comprised, in a non-differentiated manner, what the German language of today signifies through Wissenschaft 'science', Gelehrsamkeit 'erudition/scholarship', Kunst 'art', Bildung 'culture', to which one added the art of behaviour according to the etiquette of the Court) and list (craft, with the meaning of "technical ability"). Towards the end of the $13^{\text {th }}$ century, wisheit loses its general meaning and starts to resonate with the other two terms. The entire system of the field "Verstand" (knowledge) is restructured: kunst designates the superior realm of cognition, wizzen denotes knowledge in general and what was expressed by list (technical ability), while wîsheit expresses religious knowledge (including the sense of mystical understanding). This is the manner in which Trier understands the diachrony of a field and it becomes the very purpose of his research, that is establishing the signification of each and every word through delineating it within a field and following the modification of relationships based on every variation of any term from within the respective field: "Diese ist unser Ziel. Feldgliederungswandel wird uns hier beschäftigen" ["This is our purpose. Our preoccupation is represented by the modification of relationships within the field"] (Trier, 1973a, p. 18). Analysing these transformations within a certain field diachronically means, for Trier, the optimum way of analysing historically the glossary of a language: "Zur Sprachgeschichte gehört eine Geschischte der Feldaufteilungen, oder vom Worte hergesehen eine Geschichte des Wortschatzes nach Feldern" ["A history of the elements of the field, or, starting from the perspective of the word, a history of a glossary belongs to the history of language"] (Trier, 1973a, p. 20-21).

In his later studies dedicated to the problematics of the lexical field, Trier-partially influenced by certain studies which had appeared in the meantime-reinterpreted the methodological dichotomy synchrony - diachrony, stating that Saussure's affirmation about the impossibility of combining the two perspectives, synchronic and diachronic ("L'opposition entre les deux points de vue-synchronique et diachronique-est absolue et ne souffre pas de compromis", Saussure, 1922, p. 119) is not adequate for the study of language, and, on the contrary, it proves to be necessary: "Saussures Cours de linguistique générale wurde mir früh bekannt und wichtig. Für die Klärung des Gedankens von der Interdependenz der Elemente verdanke ich dem Buche viel. Aber seinem Verbot, synchronische und diachronische Sprachbetrachtung zu verbinden, konnte ich mich nicht unterwerfen" "I had knowledge of Saussure's course in general linguistics and it was important for me right from the beginning. I owe a lot to this book, as far as clarifying thought through the interdependence between elements is concerned. But his interdiction regarding the combination between the synchronic perspective and the diachronic perspective is not something I can conform to"] (Trier, 1973c, p. 459). The arguments in favour of his stepping away from Saussure's principle follow a series of observations made by Walther von Wartburg, concerning the need 
for diachronic research in view of establishing the signification of a word, because in some situations the synchronic perspective is insufficient and could lead to false descriptions of a linguistic reality (Wartburg, 1931; 1972; 1946, p. 123-177).

Wartburg's demonstration is particularly known for highlighting the evolution in the Gascon dialect of the Latin gallus in relationship with cattus. Having become homonyms at a certain point, the homonymic term in the Gascon dialect for Lat. gallus, * gat, is replaced by a synonym existing at that moment in the language, bigey (< Lat. vicarius), a fact that could only be apprehended by combining the synchronic and diachronic perspectives: "Darin liegt der innere kausale Zusammenhang zwischen der Diachronie AB, die das Wort bigey als pittoreskes Synonymon neben gallus «Hahn» stellt, und der Synchronie B, deren Spannung bigey an die Stelle von gallus treten lässt. Nur durch eine Verbindung der beiden Betrachtungsweisen ist es in jener Abhandlung möglich geworden, Gilliérons Beispiele zu interpretieren, als er selbst es getan hat, und ihnen einen neuen Sinn zu geben" ["Behind this phenomenon lies a causal, internal interdependence between the diachrony $\mathrm{A}-\mathrm{B}$, which places the word bigey as a picturesque synonym next to gallus, and synchrony B, whose tension makes bigey replace gallus. Only through a correlation of the two perspectives could one interpret in that study Gilliéron's examples differently compared to the manner in which he interpreted them himself, and consequently one could attach new meanings"] (Wartburg, 1972, p. 6). However, just as Trier himself notices, Wartburg's entire demonstration is also based on the one designed by Saussure (Trier, 1973b, p. 123).

Trier's conclusion is that there is a certain interdependence between synchronic linguistics and diachronic linguistics within the study of lexical fields, but this fact does not modify substantially the Saussurian dichotomy, but merely acts as its further development. Essentially, it is all about the understanding of the evolution of language through resorting to the corresponding timely perspective, as no word is equal to itself in different stages of the language throughout history. That is precisely the object of study chosen by Trier, but to these inequalities one has also added the element of reconstructing the balance around that particular word, namely the analysis of the lexical field.

Trier equates the signification of the lexical field with the history of an onomasiological field, because, for him, describing a lexical field involves delineating an onomasiological field and the signification of each word through its relationships to the other words in the same field, then following this complete structure of the field throughout a certain period of time, observing the shifts which appear in the signification of words within the field as a whole: "Die Feldbetrachtung ist ein praktisches Hilfsmittel, und sie ist ein solches aus einer Notlage der praktischen Wortforschung entstanden, nämlich aus einer Notlage der diachronisch arbeitenden Bezeichnungslehre, der historischen Onomasiologie" ["The perspective of a field is a practical auxiliary tool, which has appeared as such due to a necessity linked to the practical study of the word, namely out of a need for a theory of signification analysed diachronically, of a historical onomasiology"] (Trier, 1973b, p. 456).

So, diachrony represents one of the essential traits of the lexical field, for Trier. Delineating the lexical field is done through synchrony, but the reliance of establishing signification on reciprocal relationships is demonstrated in diachrony, where any modification at the level of one element is reflected upon the system of the respective field. His conclusion is that there is an interdependence between the synchronic and diachronic perspective: "Unter dem Leitstern des Gedankens der Umgliederung ist das Ineinandergreifen von deskriptiver und historischer Sprachwissenschaft nun auch da hergestellt, wo es sich um Sprachinhalte und ihre Änderungen handelt" ["So, even in the case of a linguistic content and the transformations to which it is subjected, one can prove that the leading principle of the concept of re-organization is the interdependence between descriptive linguistics and historical linguistics"] (Trier, 1973c, p. 128).

The study of the lexical field having both perspectives as starting points, as well as focusing on the diachronic perspective, is to be perceived within the adequate scientific context of the moment. Saussure had imposed the synchronic linguistic realities, but they were situated at the abstract level of language. For the research of practical realities there were no linguistic tools available for pointing out the differences in semantic content among words forming a lexical field. The only possibility to demonstrate the 
interdependence between the elements of a field was its diachronic description, this description displaying transfers of content from one term to another, and a restructuring of a field through new additions. Thus, one can say that diachrony was not a mere valid option in this case, but also the only methodological possibility provided by linguistics at that moment. We can say that Trier and Wartburg were constrained by limits of the linguistics of that time to demonstrate the interdependence and the transfer of signification within a lexical field through a diachronic approach. Other linguists who tackled the issue of lexical fields failed to take into consideration explicitly the relationship between synchrony and diachrony.

\section{The modern perspective and diachronic variation}

The complex issue of lexical fields was to be overtaken later by Eugenio Coseriu. His contributions represent the second major stage of the history of research in this area, a stage different from the first one not through selecting a historical period per se, but through an analysis of the same reality from a different perspective. His first article in which he tackles the problematics of lexical fields (Coseriu, 2001a) is focused on the possibility of describing the relationships between the signified by resorting to the tools provided by structural linguistics. The diachronic structural semantics suggested by Coseriu does not have in view, however, the diachrony of a language, but the passing of structures from one language into another, namely from Latin to Romanic languages. In this context, one has to mention the fact that structural semantics does not represent, for Coseriu, a "structuring" of lexical units in a language (exactly what the first theorists of the lexical field had expected to find), but only an identification of the structural areas of vocabulary (Coseriu, 2001a, p. 274-275).

As far as the variability of language is concerned, Coseriu always situated himself at the level of "functional" language, defined as following: "the object that Ferdinand de Saussure had in mind and dreamed of is this functional language, the unitary linguistic system which is not only synchronic, but also syntopic, single-layered, monophasic, without difference-neither upwards and downwards, nor to the right and to the left" (Coseriu, 1994, p. 60). Thus, the problem of diachronic variation is not included in Coseriu's actual discussions, his preoccupation being the one of finding a language which does not even contain synchronic variations. This fact must not be interpreted as moving away from variation in the study of language, but as an understanding that every "functional" variation, that is, a variation which implies other oppositions, belongs to a different functional language, like a dialect or a jargon.

For that matter, Coseriu states this clearly: "Cela ne signifie pas non plus qu'on devrait ignorer la variété de la langue («description structurale» ne signifie aucunement «réduction» de la langue historique à un seul système). Cela signifie uniquement que tout opposition doit être établie et décrite dans la langue fonctionnelle à laquelle elle appartient et que, pour chaque point d'un domaine quelqonque de la langue, la description doit être faite autant de fois qu'il y a des structures différentes, devant une «langue» à décrire, on décidera, en chaque cas, si sa différenciation interne est telle qu'elle exige qu'on la decrive comme une «collection» de langues différentes ou s'il y a lieu d'en choisir une langue fonctionnelle de base et d'opter pour une description «à étages» de tous les points de sa structure pour lesquelles des différences diatopiques, diastratiques ou diaphasiques se présentent, par rapport à la langue fonctionnelle choisie" (Coseriu, 2001b, p. 243-244).

Such a description "on levels" would suit the lexical fields of a language, description which could also include diachronic, next to diatopic, double-layered and biphasic differences, the diachronic ones being nothing else but former diatopic, double-layered or biphasic differences (cf. Wartburg, 1946, p. 123-177). But this description "on levels" remained a mere theoretical presentation, without examples. Coseriu's works focused on the synchronic description of lexical fields. Structural semantics provides the possibility of describing the content of a word through a sum of significant semantic units. In this manner, the differences of content can be quantified, which gives rise to the possibility of a straightforward analysis of the elements of a field from a synchronic perspective, that of identifying the signification content which distinguishes each element, comprising one or more semantic features. The structure of a lexical 
field can also be established through synchrony. A diachronic perspective would imply the analysis of changes which appear at the level of relationships within a field, together with modifying one or more terms. For example, a word such as the Romanian mindru belongs to three different areas of Romanian vocabulary. With the first meaning, the etymologic one ("wise, intelligent") it establishes a relationship with terms from the old Romanian language, whose significations refer to intellectual capacity. With the first derivative meaning, "beautiful", it echoes in the terms of the same old language, but with reference to beauty, and with the same meaning it also enters the context of "folk"/"traditional". The third meaning, that of "vain" (excessively proud), already mentioned by the end of the $13^{\text {th }}$ century, it resonates with terms describing an individual's attitude towards himself/ herself and others.

\section{Practical implications of diachronic variation within the framework of the two perspectives}

The traditional perspective, assimilated by the history of an onomasiological field, had two major reflections on the practical level of linguistic research. The first one, immediate and closely following theory, is the work of Hallig \& Wartburg (1963), where we find the suggestion of a new lexicography through assimilating the contributions brought about by the research dedicated to lexical fields. The purpose of the paper is to propose a new way of organizing a dictionary, by exemplifying a section in the vocabulary in which the order of words is affected by the semantic area to which they belong, not by the alphabet. This initiative can only be usable for a relatively small section of the vocabulary, a manner in which it has already been used, but together with the addition from the diachronic perspective, which represents the second effect of the traditional theory at the practical level. What was, for Trier, an instrument to demonstrate the existence of relationships within a semantic field, later became an objective in lexicology papers dealing with onomasiological fields, even though the concept of "lexical field" appears in the title. Moreover, these papers ignore the novel direction suggested by Coseriu's works, even though this is mentioned in the introductory, theoretical part. Many of these are valuable papers, but they bear no connection whatsoever with the theory of lexical fields. Such a paper, of high academic value, is the one belonging to Escobedo Rodríguez (2001). Papers like the one mentioned above do not continue the line of thought generated by the traditional perspective, but they do not follow the modern perspective either, the latter being marked by synchrony, focusing on highlighting the types of relationships in a lexical field.

The modern perspective does not focus on diachrony, but suggests a syncronic type of research, which does not mean that the diachronic variation is ignored-similarly, the synchronic variation is also included in the scope of the study. The element imposed by the modern perspective is the method, namely delineating the content of a word at the level of language where it functions with a certain signification. For example, a word such as shovel develops an equipollent opposition, in some areas in Bukovina, with the word șfle (< Germ. Schaufel 'shovel'): lopată /with rounded edge/ : şufle /with rectangular edge/. The terms in equipollent opposition have a common nucleus and a distinctive trait equal (as far as its value is concerned) to the terms in the respective field. Coseriu's persistence in identifying the significations and oppositions within a functional language simply means resorting to the type of research which is adequate to the reality in view. Lopată with the semantic trait /with rounded edge/ and the relationship with şufle can only be valid at a regional level, in the area mentioned. Otherwise, lopată contains neither the semantic trait /with rounded edge/, nor the semantic trait /with rectangular edge/. A similar kind of variation, though on a diachronic level, can be identified for the Romanian terms vechi and bătrîn. From the synonymy relationship valid in the old Romanian language one can reach to the equipollent opposition between the terms vechi (for inanimate entities) and bătrîn (for living entities) ${ }^{1}$ These two terms are

\footnotetext{
${ }^{1}$ Using the seme /animate/ (for living entities) instead of /being/ (for beings) (cf. Coseriu, 2001a, p. 307) requires argumentation. For example, the skin, which is not a 'being', gets old, is "alive". In the case of an elderly person, one says that the skin is îmbătrîn ită, not "învechită". However, when discussing about the animal skin—"not alive" —used in the leather industry, one uses the term "învechită". Not the same thing happens in Italian, where we have vecchio for objects, plants and
} 
Dinu Moscal

today in synonymic opposition, meaning that they are parasynonyms, but in the old Romanian language they were synonymous, since both of them were used for inanimate entities and animate entities ${ }^{2}$. The knowledge of the oppositions at the semantic/lexical level, based on which one assess the existence of a lexical field, should be reflected in the lexicographic study of the respective terms. DA presents the adjective bătrîn as follows: "1. (About people) Very elderly (as opposed to tînă r, ju n e) [...]. 2. P. ext. From long ago, from the old times". A definition based on the results of the specific analysis of lexical fields should bring forward the common characteristic /long period of time/ for both terms, mentioning that $v e c h i$ is associated with /inanimate/ objects and bătrîn with /animate entities/. Changing the relationship between the two terms at the diachronic level could be specified as "(vechi) Vechi" with the article for the adjective bătrin and as a restriction with the article for the adjective vechi in the old Romanian language, not as an extension of the present signification, as it is mentioned in DA, a fact that does not correspond to the historic reality of Romanian.

So, even if what the modern perspective suggests is to clearly identify the semantic variation in lexemes and to study them as such at the level of language at which they function, this does not mean reducing semantic variants to one, that of literary norm. The exemplifications in Coseriu's studies should not lead to this idea, because they are merely illustrative, not prohibitive. The objectives of the studies corresponding to the modern perspective were essentially theoretical. The actual application of the theory should become the focus of lexicographers, but, unlike the attempts to apply in lexicography the results provided by the field analysis in the traditional perspective, the modern perspective could not gather such accomplishments. According to the subject of study identified, namely the vocabulary areas forming lexical fields, the possibilities of contributing to lexicography are reduced to the study of words belonging to a lexical field. The lack of a diachronic perspective (as a history of a language, not as the passing from one language to another) from the theoretical foundations of the modern perspective does not eliminate diachronic research in the case of organized areas (implying semantic interconnectedness) of the vocabulary of a language, just like it does not eliminate its synchronic variation. In fact, at the level of language, there is no difference between synchronic variation and diachronic variation, because the diachronic variation is nothing else than a result of synchronic variation, or, more accurately, a conservation of a synchronic variation. The examples mentioned above prove that the tools and results of the approach corresponding to the second stage of lexical fields can bring forth an important contribution to lexicography, at the synchronic as well as at the diachronic level.

\section{Conclusions}

The diachronic perspective played a crucial part in the theoretical endeavour which led to identifying lexical fields. The history of the lexical fields' theory shows that there are two distinct time frames, different as far as their methods and objectives are concerned. In the period between the 1930's and the beginning of the 1960 's, when the objective was to demonstrate the existence of lexical fields, studying the history of an onomasiological field imposed itself as the primary methodological approach. This was, the transfers of semantic content from one term to another-within the same onomasiological fieldcould be identified, and, implicitly, the relationships between the elements of that particular field could

animals, but also for people (pejoratively or colloquially: Questo vestito ti invecchia) and anziano only for people, though the skin is "i n v e c ch i a ta" (cf. Iliescu, 2008).

${ }^{2}$ To illustrate this fact, we provide a few examples from Ghibănescu (1906-1915), mentioning the volume and the page as source, with the year specified between parentheses: "seamnele ceale bătrăne" $I_{2}, 234$ (a. 1632), "hotarăle ceale bătrăne" $\mathrm{II}_{1}$, 164 (a. 1638), "casăle ceale bătrăne" $\mathrm{II}_{2}, 44$ (a. 1643), "vad de moară bătrân” $\mathrm{II}_{2}, 47$ (a. 1644), "care sat este mai bătrân” $\mathrm{III}_{1}, 48$ (cca 1647), "siliștea cea bătrână” $\mathrm{II}_{2}, 156$ (cca 1648), "zapis bătrân” " $\mathrm{II}_{2}, 187$ (a. 1649), "obcina cea bătrână” $\mathrm{III}_{1}, 86$ (a. 1657), "moșie bătrănă" $I_{1}, 86$ (a. 1686), "zapisăle cele bătrâne” $\mathrm{IV}_{1}, 204$ (a. 1692), "uricele lui cele bătrăne" $\mathrm{IV}_{2}, 39$ (a. 1702), "den zile bătrăne" $\mathrm{IV}_{2}, 76$ (a. 1753, rezumat). The phrase "țuică bătrînă" is a reminiscence from that period, just like the toponyms Măgura Bătrină (East of Cîmpulung Moldovenesc, Suceava county), Plaiul Bătrîn (West of Boboiești, Neamț county), Jijia Bătrînă (ancient riverbed of the Jijia river), or Jiul Bătrîn (pond in Dolj county). 
be defined. What had been at first a tool for research, the diachronic perspective later became a practical objective for theorists, but with certain alterations, as follows: presenting the detailed history of each term belonging to a particular onomasiological field, without any interest for the relationships between the terms. Such works are nothing more than detailed dictionaries of the history of terms belonging to an onomasiological field, even though they contain the phrase "lexical field" in the title.

For the theorists of this early phase, the diachronic approach imposed itself as a methodological necessity, not as a result of a decision in its favour, but as the only modality of demonstrating the interconnectedness between the elements of a lexical field. Designing the tools for a semantic analysis within the framework of structural linguistics allowed for setting a different objective: to identify the types of relationships between the terms of a field through identifying the particular semes. The defining trait of this second stage is the analysis of a field within the framework of a functional language, that is, within a synchronic or diachronic version of a historical language. Identifying the signification of a word at the level of the functional language to which it belongs must not be mistaken for narrowing down the study of a word to a single functional language. The research can and must take into consideration the semantic variation of the terms constructing the lexical field in both dimensions, synchronic and diachronic. The results of this type of study are useful in lexicography, the definitions and structures of articles becoming clearer and closer to the reality of the language.

\section{Bibliography}

Coseriu, E. (1994). Prelegeri şi conferințe (supliment al „Anuarului de lingvistică şi istorie literară, XXXIII, 1992-1993, Seria A - Lingvistică), Iași.

Coseriu, E. (2001a). Pour une sémantique diachronique structurale, în „L'Homme et son langage”, Éditions Peeters, Louvain Paris - Sterling, Virginia, p. 253-313, ed. I: 1964.

Coseriu, E. (2001b). Vers l'étude des structures lexicales, in „L'Homme et son langage”, Éditions Peeters, Louvain - Paris Sterling, Virginia, p. 215-252, ed. I: 1966.

DA = Diçtionarul limbii române, București, 1913-1949.

Diogenes Laertios (2001). Despre viețile și doctrinele filosofilor, traducere de C. I. Balmuş, studiu introductiv și comentarii de A.M. Frenkian, Polirom, Iaşi.

Escobedo Rodríguez, A. (1992). El campo léxico 'hablar' en español, Servicio de Publicationes de la Universidad de Granada, Granada.

Ghibănescu, Gh. (1906-1915). Ispisoace și zapise (Documente slavo-române), I-IV, Tipografia „Dacia”, Iași.

Hallig, R. \& Wartburg, W.v. (1963). Begriffssystem als Grundlage für die Lexikographie (Versuch eines Ordnungsschemas), 2. neu bearbeitete und erweiterte Auflage, Akademie Verlag, Berlin, ed. I: 1952.

Iliescu, M. (2008). Semantica descendenților romaniciai lat. vetulus, in Miscelanea Romanica (1956-2007), Clusium \& Scriptor, Cluj-Napoca, p. 221-228.

Jolles, A. (1973). Antike Bedeutungsfelder, in „Wortfeldforschung. Zur Geschichte und Theorie des sprachlichen Feldes”, Hrsg. von Lothar Schmidt, Wissenschaftiche Buchgesellschaft, Darmstadt, p. 104-115, ed. I: 1934, CrossRef.

Moscal, D. (2013). Teoria cimpurilor lexicale. Cu aplicație la terminologia populară a formelor de relief pozitiv, Editura Universității „Alexandu Ioan Cuza”, Iași.

Porzig, W. (1973). Wesenhafte Bedeutungsbeziehungen, in „Wortfeldforschung. Zur Geschichte und Theorie des sprachlichen Feldes", Hrsg. von Lothar Schmidt, Wissenschaftiche Buchgesellschaft, Darmstadt, p. 78-103, ed. I: 1934, CrossRef.

Saussure, F. de (1922). Cours de linguistique générale, publié par Ch. Bally et Al. Sechehaye avec la collaboration de A. Riedlinger, Payot \& Cie, Paris.

Trier, J. (1973a). Der deutsche Wortschatz im Sinnbezirk des Verstandes. Von den Anfägen bis zum Beginn des 13. Jahrbunderts, Zweite Auflage, Carl Winter Universitätsverlag, Heidelberg, ed. I: 1931.

Trier, J. (1973b). Deutsche Bedeutungsforschung, in „Wortfeldforschung. Zur Geschichte und Theorie des sprachlichen Feldes”, Hrsg. von Lothar Schmidt, Wissenschaftiche Buchgesellschaft, Darmstadt, p. 116-128, ed. I: 1934.

Trier, J. (1973c), Altes und Neues vom sprachlichen Feld, in „Wortfeldforschung. Zur Geschichte und Theorie des sprachlichen Feldes", Hrsg. von Lothar Schmidt, Wissenschaftiche Buchgesellschaft, Darmstadt, p. 453-464, ed. I: 1968.

Wartburg, W. v. (1931). Das Ineinandergreifen von deskriptiver und historischer Sprachwissenschaft, in „Berichte über die Verhandlungen der Sächsischen Akademie der Wissenschaften zu Leipzig. Philologisch-historische Klasse", 83/1, p. 1-23.

Wartburg, W.v. (1946). Problèmes et méthodes de la linguistique, PUF, Paris.

Wartburg, W.v. (1972). Betrachtungen über das Verbältnis von historischer und deskriptiver Sprachwissenschaft, in „Mélanges de linguistique offerts à Charles Bally", Slatkine Reprints, Genève, p. 3-18, ed. I: 1939.

Weisgerber, L. (1973), Vom inhaltlichen Aufbau des deutschen Wortschatzes, in „Wortfeldforschung. Zur Geschichte und Theorie des sprachlichen Feldes", Hrsg. von Lothar Schmidt, Wissenschaftiche Buchgesellschaft, Darmstadt, p. 193-225, ed. I: 1939. 